\title{
SLOPE FAILURES AND CROSS-VALLEY PROFILES, Grand Teton NATional PARK, WyOMIng
}

\author{
RICHARD A. MARSTON $\downarrow$ BRANDON J. WEIHS $\downarrow$ WILLIAM D. BUTLER \\ DEPARTMENT OF GEOGRAPHY $\downarrow$ KANSAS STATE UNIVERSITY $\downarrow$ MANHATTAN
}

\begin{abstract}
$\uparrow \quad$ Abstract
This project described and explained the pattern of slope failures (falls, slides, flows, snow avalanches) and the shape of valley cross-profiles in five canyons of Grand Teton National Park. Shapefiles were created in ArcMap 9.3 for slope failures using existing data sets plus newly mapped failures. Valley cross-profiles were prepared for 44 locations in the canyons using digital elevation models (DEMs). The distribution of slope failures were found to be related, to various degrees, to slope aspect, distance from the Teton Fault, rock mass strength, Schmidt rock hammer values, and slope gradient. Shape files were generated that show sections of hiking trails and camping zones that have been impacted by past events. Valley cross-profiles are best represented by a parabolic curve, and the value of the coefficient in the equation describing those curves is related to Schmidt rock hammer values and rock type. These findings have direct implications for backcountry recreation in the canyons and for visitor interpretation of canyon scenery.
\end{abstract}

\section{$\downarrow \quad$ INTRODUCTION}

\section{Problem Statement}

The shape and size of cross-valley profiles in deglaciated mountain canyons are generally recognized to be a function of rock resistance, past glacier characteristics, and time (glacier chronology and time since glaciation). Cross-valley profiles are also affected by slope failures (rock/debris falls, slides, flows, and snow avalanches), which can also pose hazards for mountain recreation. However, the patterns and controls on these phenomena are not yet well documented for Grand Teton National Park (GTNP).

\section{Purpose and Objectives}

The purpose of this project was to describe and explain the geographic patterns of glacial valley cross-profiles and slope failures in five canyons of GTNP, Wyoming. Specific objectives were to:

1) Map slope failures (rock/debris falls, slides, flows, and snow avalanches) and identify the key variables that control their distribution.

2) Draw valley cross-profiles, fit a mathematical curve to the data, and determine the factors that affect valley shape.

3) Discuss the implications of 1 and 2 above to park management.

\section{Significance}

Canyons of the Grand Teton Range are used extensively by day hikers, backpackers, and rock climbers. Past slope failures have greatly modified the post-glacial canyon walls and have directly impacted trails and camping zones. This project intends to identify areas that are particularly prone to rock/debris falls, slides, flows, and snow avalanches. The canyon scenery has been shaped by past glacial episodes and subsequent slope failures (Figure 1). Interpretation of the canyon scenery, through interpretative signs and guidebooks, is one goal of the National Park Service, so this project has the potential for improving the visitor experience and appreciation of the Teton landscape. 


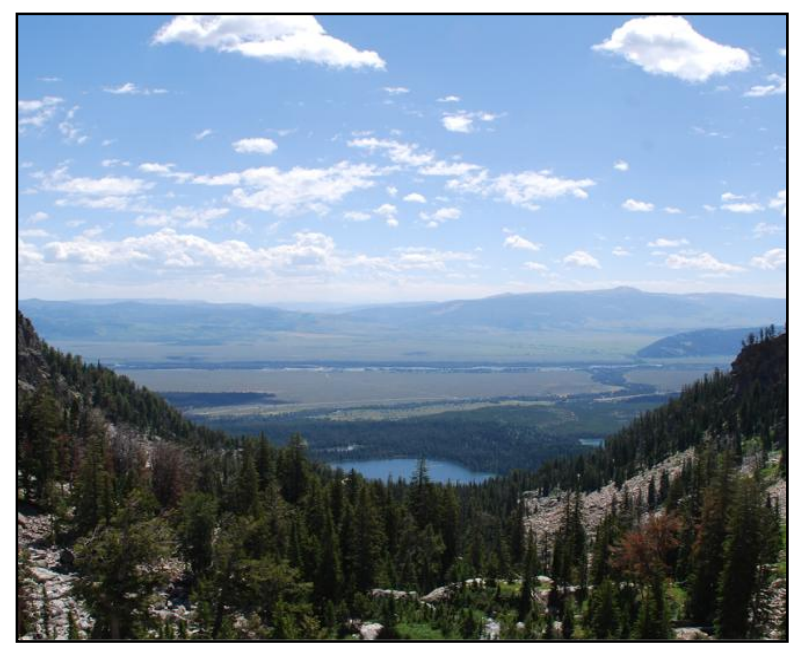

Figure 1. View down Garnet Canyon from trail. Note the parabolic valley cross-profile and the rock fall deposits on both slopes.

\section{$\downarrow$ BACKGROUND}

\section{Slope Failures}

Mountains are affected by slope failures, classified by material involved (rocks, fine or coarse textured earth debris, or snow) along with the type and speed of movement. Slope failures comprised of either rock or unconsolidated earth debris can be classified as falls, slides, and flows. Many slope failures are complex combinations of falls, slides, and flows.

A fall is a rapid type of slope failure where rocks or debris are released suddenly along a tension fracture on a cliff and the earth material falls under the direct influence of gravity. Alexander (1993) defines rock falls as mass movements that "occur through the air" from exposed rocks that are jointed and fractured on the edges of cliffs. The material commonly accumulates on a slope in the form of a talus cone (if originating from a single point on the cliff) or as a more continuous talus slope.

A slide can also be composed of rocks or fine/coarse earth debris. The movement is "en mass" along a failure surface, either a plane or concave-up rotational failure surface, in which case the failure is known as a slump. Slides can range in velocity from slow to rapid.

A flow can occur as a rock flow, perhaps cushioned by air as it moves rapidly downslope. These events are also known as rock avalanches or blockstreams (Degenhardt et al., 2007). Another form of flow common in mountains is the debris flow (if earth material is coarse in texture) or earthflow (if earth material is fine). Flows can be very rapid or extremely slow. The latter form is known as creep. Sidle and Ochiai (2006) note that debris slides and flows initiate on concave or linear slopes and are often started by quick rates of snowmelt, tectonic activity, and rainstorms.

Snow avalanches comprise the fourth major class of slope failures in the Teton Range. Alexander (1993) defines these movements as the result of snow packs on slopes experiencing structural instability to the point of snow movement. He also outlines the slope gradients at which snow avalanches are considered to be common and uncommon events. Small avalanches commonly occur at angles of 35 to 75 degrees, occasionally from 25 to 35 degrees, and rarely to non-existent for gradients below 25 degrees and above 75 degrees. Large avalanches commonly occur at gradients of 25 to 50 degrees, less commonly from 50 to 70 degrees, and rarely to non-existent for gradients below 25 degrees or above 70 degrees. Patten and Knight (1994) state that snow avalanches also significantly affect vegetation patterns in the park, as evidenced by their study in Cascade Canyon. One can readily identify past snow avalanche paths on aerial photography, satellite imagery, and Google Earth by locating "scars" of brush or grass on a landscape where trees have been destroyed.

Slope failures can be triggered by a number of driving forces, including:

1) Loading of slopes with weight (e.g., from water);

2) Vibrations (e.g., earthquakes);

3) Removal of lateral support (e.g., streams undercutting of toe of hillslopes); and

4) Loss of strength in earth materials by increased pore water pressure (in fine textured earth materials), fissuring, solution of cementing materials, loss of cohesion affected by plant roots.

The Teton Range is the product of highangle block-faulting, so seismic activity will have a consistent presence at the front of the range and may trigger all four major classes of slope failures. Keefer (2002) provides a review of numerous studies that show how seismic activity can cause slope failures to occur, and Harp et al. (1981) provided the first attempt to map these seismically-induced slope failures. Therefore, treating the Teton Fault as a potential trigger of slope failures in the five canyons appears to be justified. 


\section{Glacier Valley Cross-Profiles}

The second objective of this study was to describe and explain the cross-profile shape of glacially eroded canyons, including the effects of slope failures. Studies concerning the geomorphological characterization of deglaciated mountain valleys have typically focused on the mathematical explanations of deglaciated valley cross-profiles, paired with the examination of hypothesized variables believed to govern profile morphology.

Modern textbooks describe the cross-valley profile of deglaciated terrain as U-shaped (Christopherson, 2009; Plummer, et al., 2010; Love, et al., 2007), however connotations of the forms have been debated for approximately a century. According to several authors, Davis (1916) was the first to suggest that deglaciated cross-valley profiles are catenaries, which are the curves produced when a flexible, but non-stretchable cord, hangs freely from two points (Graf, 1970; Hirano \& Aniya, 1988, 1989, 1990). This notion was followed by the work of Svensson (1959), who was the first to describe deglaciated cross-valley profiles as parabolas using the equation $\mathrm{Y}=\mathrm{a} \mathrm{X}^{\mathrm{b}}$, where $\mathrm{Y}$ is valley height, $\mathrm{X}$ is valley width, and $a$ and $b$ are coefficients (Graf, 1970; Hirano \& Aniya, 1990). Much literature since Svensson's (1959) work has been concerned with defining the parabolic shape of deglaciated valleys using equations that have "evolved" with the addition of coefficients. An example of this "evolution" can be seen in the work of Wheeler (1984), who proposed the quadratic equation $\mathrm{Y}=\mathrm{a}+\mathrm{bX}+\mathrm{cX} \mathrm{X}^{2}$ (Augustinus, 1992).

Most studies characterizing deglaciated mountain valley morphology are concerned with both the shape (described by equations) of the valleys, as well as the controls of form development. Graf (1970) studied the application of fluvial concepts to glacial geomorphology, namely the effects of bifurcation ratios and the laws of stream (glacier) numbers, and stream (glacier) lengths, and Penck's law in the Beartooth Mountains of northwestern Wyoming. Harbor et al. (1988) and Harbor (1992, 1995) were concerned with mathematical modeling of deglaciated cross-valley profiles through time, and found that the a key factor was the increased erosion at the thalweg of glacial channels, a result of "weaker" rocks and higher basal ice velocity in the thalwegs of glacial valleys than at the margins. Augustinus (1992, 1995) postulated that cross-profile morphology in the Southern Alps of New Zealand is a "direct consequence of the rock mass strength properties of the slope rock." (Augustinus, 1992, p 39) Hirano and Aniya (1988, 1989, 1990) investigated the differences between alpine and continental glaciations based on cross-profile morphologies (curve analyses) from other studies (including Graf 1970), and concluded that alpine glaciations are prone to overdeepening, while continental glaciations produce considerably wider subglacial valleys with different form ratios. Seppala (1978) investigated faulting and rock jointing as paramount variables in cross-valley profiles for the Lemon Creek and Ptarmigan glaciers in the Juneau Ice Field of southeastern Alaska. He found that faulting controlled the general direction of the valleys, while jointing controlled the symmetry of the cross-valley profiles.

Augustinus (1995, p 95) remarked that the need exists to develop realistic models that link glacier processes with "a scheme that incorporates feedbacks created by input of subaerial processes...rock mass strength and stress-induced weakening of the rock mass". Harbor (1995) also noted that "future work should address more complex patterns of rock resistance to erosion, as well as nonglacial processes operating on slopes above and beyond the glacier margin" (Harbor, 1995, p 106). Brook et al. (2004) state that rock strength is an important control on glacial valley morphology. Their assertion is that rocks with higher strength values will produce steeper valley slopes, while lower strength values will produce broader valley slopes. If slope gradient is a major control on the periodicity of slope failure occurrences, then rock strength must also be considered as a critical factor.

An easy, and inexpensive, way to measure rock strength is with a Schmidt rock hammer. Moon and Selby (1983) played an integral role in transitioning the Schmidt hammer as a tool for the concrete industry to an instrument used to measure Rock Mass Strength (RMS), a measure of rock stability. The technique was originally pioneered by Selby (1980) and subsequently used by Selby (1982) in the Central Namib Desert, and Moon and Selby (1983) in locations across southern Africa. RMS uses both intact rock strength measured by the Schmidt hammer and data about the joints and weathering of a rock to determine rock stability, which can be used to determine the angle at which the slope of a given landform is at equilibrium. Moon (1984) further refined the RMS technique by adding further subdivisions for intact rock strength and joint spacing. Viles et al. (2011) discuss the current debate over sampling methodology for Schmidt hammer measurements in geomorphic studies. Owen et al. 
(2007) studied chemical weathering rates of rock in Norway by using the Schmidt hammer, and they found that periglacial (physical) erosion after the Little Ice Age overwhelmed all topographic changes caused by chemical weathering.

This study, which focuses on post-glacial morphology of valley cross-profiles, is spurred by these past studies, in that past authors have made it clear that rock resistance, glacier characteristics, and time (glacier chronology and time since glaciation) must be considered together to further understand the development and form of deglaciated valleys, including post-glacial and future mass movement (Marston, 1998, 2010).

The combined youth of the Teton Range and the periodicity, size, and ages of glaciations make this an ideal site for studying recently deglaciated terrain and quantifying the effects of post-glacial processes on cross-valley morphology and slope failures (Pierce and Good, 1992; Love et al, 2007). Slope failures are particularly hazardous in oversteepened mountain canyons of the Tetons, but detailed maps and statistical analyses are lacking. To understand the hazard for mass movement, it is critical to distinguish between talus, debris flows, avalanche, protalus ramparts, glacial moraines, rock glaciers and other types of coarse debris deposits such as block slides.

The working hypothesis of this proposed study was that the coefficients in the Augustinus (1992) equation will vary by rock mass strength, glacier characteristics, and time. The parabolic shape is also modified by post-glacial geomorphic processes, including by mass movement and fluvial action. The effects of these post-glacial processes on the parabolic cross-valley shape have not been modeled.

\section{$\downarrow \quad$ STUDY AREA}

The Teton Range is located in northwestern Wyoming at about latitude $43^{\circ} 46^{\prime} 46^{\prime \prime} \mathrm{N}$ longitude $110^{\circ} 50^{\prime} 10^{\prime}$ 'W, which is approximately $10 \mathrm{~km}$ west of the south-flowing Snake River and approximately $5 \mathrm{~km}$ east of the Wyoming / Idaho state border (Figure 2). The range is approximately $70 \mathrm{~km}$ long and $20 \mathrm{~km}$ wide, and is the first topographic barrier to moist Pacific westerlies moving through the western Snake River Plain (Foster et al., 2010). Orographic uplift of moist air masses has contributed to glaciations in the Teton Range to cause "elevated peaks high above the surrounding topography"

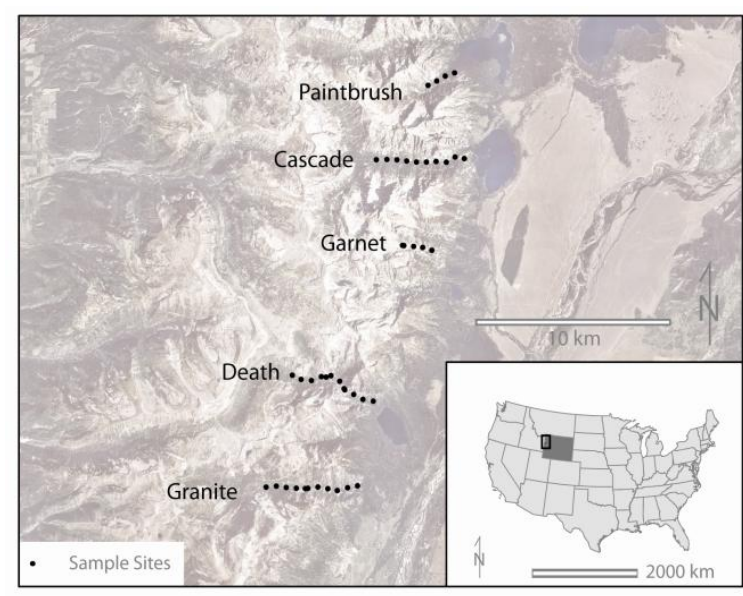

Figure 2. Study canyons and sample sites.

(Foster et al., 2010) containing isolated summits, or "topographic lightning rods" (Brozović et al., 1997; Foster et al., 2010).

The climate of GTNP at present is considered to be continental and highly variable (Vankat, 1979), having cool summers (such as nearfreezing morning temperatures in July) and cold winters that are typically the lowest temperatures in the U.S., excepting parts of Alaska. According to Mahaney (1990), mean annual temperature for mountain basins is $-4^{\circ} \mathrm{C}$, and mean annual minimum and maximum temperatures are $-12^{\circ} \mathrm{C}$ and $3^{\circ} \mathrm{C}$, respectively. Precipitation in the Rocky Mountains is also quite variable $(40-150 \mathrm{~cm})$, according to Vankat (1979), however, Foster et al. (2010) modeled precipitation using 30 year weather station records and found that precipitation can reach over $200 \mathrm{~cm}$ at the highest elevations in the range. Love et al. (2007) also note (quoting Love et al., 2007, p 95) that "modern patterns of precipitation are broadly comparable to those found in the LGM".

The Teton Range is the result of active crustal extension (normal faulting) and is the youngest range in the Rocky Mountains at approximately 2 million years old (Good \& Peirce, 2002). This mode of orogeny sets the Tetons apart from other older (at $\sim 60 \mathrm{Ma}$ ) surrounding ranges in the region, such as the Snowy, Laramie, Bighorn, Beartooth, Wind River, and Absaroka Ranges, which are the result of crustal shortening that produced reverse faulting (Lageson and Spearing, 1991). Uplift rates for the Teton Range are among the highest recorded in coterminous US, at $0.8 \mathrm{~mm} / \mathrm{yr}$ (Roberts and Burbank, 1993; Foster et al., 2010).

The lithology of the Teton Range is a mixture of crystalline Archean basement rocks 
overlain by Paleozoic and Quaternary sediments (Love et al., 1992). The eastern flank of the range is largely free of Paleozoic rocks, due to back-tilting of the western flank (Foster et al., 2010). This backtilting has resulted in asymmetry of the range, with high crystalline "teflon" peaks in the east, and low slopes to the west.

In terms of glaciations, the Teton Range is quite unique in that at least three separate glaciations have occurred there during the Pleistocene. The Buffalo glaciation was the oldest, at around $200 \mathrm{ka}$, and is said to have been the most widespread of the three, having filled Jackson Hole with $\sim 650 \mathrm{~m}$ of ice (Lageson and Spearing, 1991). The Bull Lake glaciation followed the Buffalo glaciation, and is dated around 200 to $130 \mathrm{ka}$ (Lageson and Spearing, 1991). The most recent glaciation that occurred in the Teton Range was the Pinedale, which took place between 30 to $15 \mathrm{ka}$ (Peirce, 2003). This glaciation was considerably smaller in magnitude compared to the Buffalo and Bull Lake glaciers, which had the effect of incising smaller troughs within the larger Bull Lake troughs. This lesser amount of Pinedale ice created breaks in slope called trimlines, or "shoulders", on valley walls. Other notable features from the Pinedale glaciation exist in Jackson Hole, such as moraine dammed lakes (Jenny, Leigh, Jackson, plus others), which are a proxy for the most recent glacial extent.

The flora of GTNP today is considered to be montane coniferous forest, according to Vankat (1979). This classification can be described as a mixture of altitudinal "bands" that vary with elevation, but show the same trend with changes of latitude (Vankat, 1979). In general, GTNP is dominated by coniferous trees such as Abies lasiocarpa (sub-alpine fir), Abies menziesii (Douglas fir), and Pinus contorta (Lodgepole pine), but deciduous trees are also present, such as Populus tremuloides (Quaking aspen). In the floodplains and bottomlands, Salix spp. (willow) and Artemisia spp. (sagebrush) shrubs dominate, with various grasses and herbs existing sporadically as well. Vegetation, in the most basic of terms, decreases with altitude, and there is very little biomass above $2800 \mathrm{~m}$. Vegetation of GTNP during the Pinedale glaciation would have resembled tundra conditions found only in the northernmost latitudes today. Good and Pierce (2002) described GTNP during the Pinedale as "a treeless plain", due to the incredible amount of meltwater coming out of the snout of the Jackson Lake glacier.

Soils in Teton Range canyons have been described by Mahaney (1990) as poorly developed, shallow (23-68 cm), entisols (Cryorthents) and inceptisols (Cryocrepts). In general, soils are extremely young with few structures and diffuse horizonation.

Slope failures occur at extremely high rates in Teton Range. This high-frequency of mass movement is largely due to tectonic and climatic forcing, coupled with the effects of variable rock types and weathering, and post-glacial debuttressing of valley walls. These colluvial processes further complicate / perturb the "misfit" fluvial regime with high and frequent debris / rock inputs which overload or even dam streams, causing epicyclical responses (Hewitt, 2006) to the constant / chaotic inputs of mass movement. This situation of continual or extended disruption of a fluvial regime has been discussed by Hewitt (2006) as a "disturbance regime", which refers to "the long-term or permanent consequences of relatively brief, but reoccurring episodes, usually of high magnitude or at critical sites", which produce landforms "whose location and history and are dependent on the disturbances" (Hewitt, 2006, p.367). According to Hewitt (2006, quoting Benda et al., 2003), the landforms of a disturbance regime "tend to be polygenetic and exhibit morphological heterogeneity", also called "patchy heterogeneous morphologies" (Burchstead et al., 2010). Though Hewitt was mostly concerned with mega-scale rock avalanches, or sturzstrom (Shroder \& Weihs, 2010), the same phases of the landslide interruption epicycle are observable in Teton canyons.

Human land use is minimal in the upper reaches of most canyons in the Teton Range, having very little infrastructure excepting sporadic ranger stations, camping zones, and maintained hiking trails with timber bridges. In most respects, the Teton Range is "pristine", with virtually no direct impacts from human alteration, excepting trails, camping zones, and ranger stations that have been designed and maintained to have minimal footprints on the landscape. Beyond the mouths of the canyons though, human land use bustles, affording ski resorts, vacation homes, and GTNP to the 2.7 million (US National Park Service, 2010) annual visitors and tens of thousands of local residents. Ranching is a noticeable land use in the Snake River plain, and agriculture involving tilling is virtually non-existent. Despite the large human use of private and public lands in the area, it is flanked on nearly all sides by national forests / parks, as well as an elk refuge directly north of the city of Jackson, which limits human "interference" with natural systems to a large degree beyond the periphery of trafficable areas. 
$\uparrow \quad$ METHODS

\section{Slope Failures}

To begin the process of mapping slope failures for the five study canyons, the slope failure data set from the Case (1989) "Landslide map of Wyoming" (for Teton County) was imported into ArcMap and laid over a full color orthorectified image (NAIP) of GTNP. Four primary categories of slope failures were used to group the Case (1989) data: rock falls, slides, rock/debris flows, and snow avalanches. Case's (1989) data were then further reduced to only include slope failures located within clear view of the sample sites in the five canyons. Other data imported from the National Park Service included locations of hiking trails and camping zones.

Additional slope failures were identified and mapped in ArcMap using multiple methods: analyses of orthorectified imagery and Google Earth imagery, field reconnaissance, and photographic documentation. The full color orthorectified image provided an initial two-dimensional view of slope failure locations, while Google Earth provided a three-dimensional view to fully identify the type and shape of each deposit polygon in ArcMap. Field reconnaissance and photographic documentation provided an additional method in determining slope failure size and shape, particularly at the sample sites of each canyon.

Photos were taken of both the north and south-facing slopes of the canyon to document these profiles (Figure 3). These photographs were used in to identify the types and shapes of slope failure polygons at each sample site.

Catchment areas $\left(\mathrm{m}^{2}\right)$ were extracted/created from data provided by the National Hydrology Dataset (NHD), as well as DEMs provided by the USGS. These analyses were performed using ArcHydro in ArcMap 9.3. The parameters of the catchment areas included any drainages directly pertaining to the sample sites in each canyon and drainages within 50 meters of the beginning and end of each canyon's sample site.

Field methods included rock-mass-strength (RMS) measurements taken at a sample frequency of $0.5 \mathrm{~km}$ along five trunk- streams in the range (Table 1), as well as photo documentation and visual observations. RMS was quantified based on the methodology employed by Moon (1984) and described by Dackombe and Gardiner (1983), which involves the measurement of seven properties (Table $1)$.

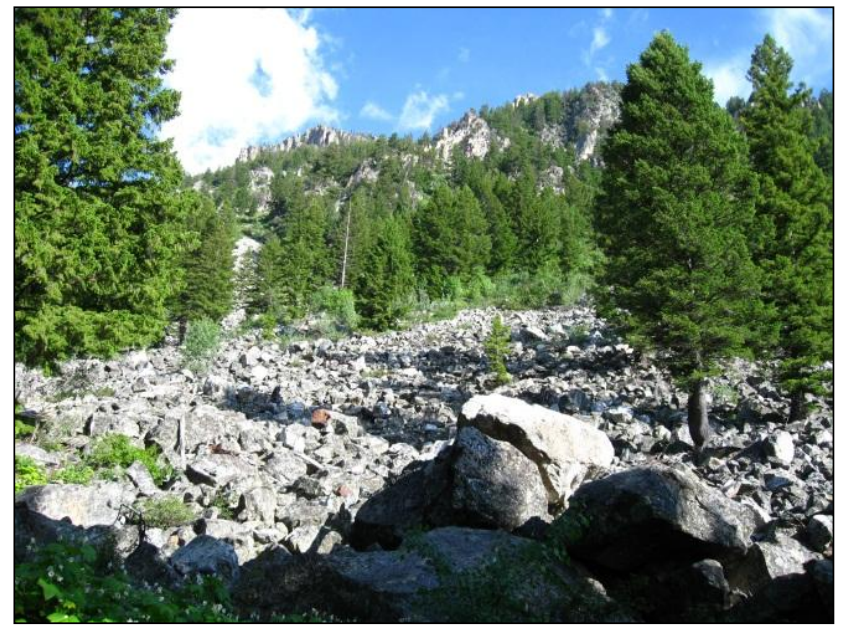

Figure 3. South-facing slope at site \#1 in Granite Canyon. Note the presence of a debris flow intruding directly onto the Granite Canyon trail.

Table 1. Rock mass strength classification, modified from Moon (1984).

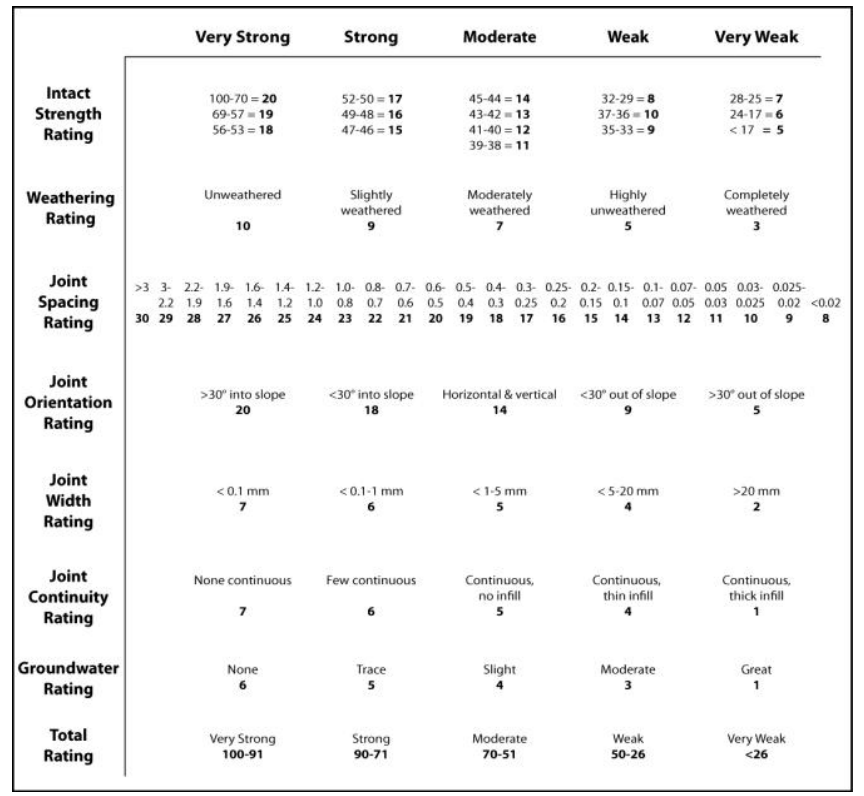

The methods used to acquire different rock properties vary; however, the end result is that each property is assigned an "r value" that is summed with the others for each sample to produce a total rating of rock mass strength. Intact rock strength sampling required the use of a Schmidt hammer (type ' $R$ ') and several measurements from a single sample location were averaged. Rock weathering and fracture continuity were qualitative assessments. Joint spacing $(\mathrm{mm})$ and width of joints $(\mathrm{m})$ was measured 
using visual observations and measurements, and GPS devices. Joint orientations were measured using a Brunton pocket transit and/or visual observations to obtain strike and dip values where possible. The outflow of groundwater from each rock sample was obtained by qualitative descriptions of water output. Compressive strength of each rock tested with the Schmidt hammer was also recorded.

Each type of slope failure in the five canyons was mapped separately to help determine the overall distribution patterns and the factors affecting the slope failures. Areas $\left(\mathrm{m}^{2}\right)$ of each deposit polygon were extracted using ArcMap, while the numbers of each type of slope failure in the canyons were also counted and analyzed statistically.

Slope failure source points were created in an effort to sample several variables related to slope failure where it is initiated. These points were subdivided by slope failure type (falls, flows, slides, and avalanches). Slight differences existed in source point placement methods between slope failure types. For example, debris flow deposits are often result of the convergence of several linear features (channels/ravines) which combine and produce a single deposit, whereas falls, slides and avalanches have single source cliffs, slopes, or slope facets. Flow source points were placed at positions $\sim 1 / 3$ of the total length of the channel from the channel/ravine heads. The remaining source points (falls, slides, and avalanches) required a single point for each deposit polygon. Fall and slide source points were placed directly above deposit polygons, typically on the upper bounds of rock cliffs, or detachment scars, respectively. Avalanche source points were placed directly inside avalanche deposit polygons (near the tops) due to the fact that avalanche deposit delineations include both the deposits, as well as their run-out zones. This allowed source points to sample conditions causing the avalanche, not the resultant deposition area.

Once placed, slope failure source points could be used to extract several types of data in ArcMap 9.3, including:

1) Elevation (m)

2) Slope (deg)

3) Aspect (deg)

4) Distance to the Teton Fault (m)

5) Rock type

6) Position above/below the Pinedale Glaciation berm
These source point data were then coupled with the appropriate deposits, as well as organized by canyon/sample site locations so that RMS data could be appended to the source point data. Slope failure polygons were also analyzed in ArcMap for similar, but not identical, data types. These data include:

1) Elevation (m)

2) Aspect (deg)

3) Distance to the Teton fault (m)

4) Relative trimline position

Once joined, these data served as the focus of further statistical analyses concerned with the presumed causes of initialization of mapped slope failures. Once compiled, the master dataset for slope failures was entered into Statistix 9.0 so that histograms could be inspected and chi-square analyses could be performed. In this manner it would be possible to identify how each environmental variables controls each type of slope failure.

This study also examined the current and potential impacts that slope failures may exert on GTNP trails and camping zones. For park trails, the total length of trails $(\mathrm{m})$ intersected by an already documented slope failure polygon were counted and analyzed for each canyon using the clip function in ArcMap. Distances of trails potentially affected by slope failures within a 100 meter radius of a park trail were recorded via use of the measurement tool in ArcMap. The outermost edge of each slope failure polygon that faced the trail was used for these measurements. The length of GTNP trails intersected and/or potentially intersected by each slope failure type was also measured. Areas $\left(\mathrm{m}^{2}\right)$ of camping zones intersected by the four categories of slope failures were also recorded for each canyon using ArcMap's clip function. Potential slope failures affecting camping zones were analyzed in a qualitative table stating the slope failure type, campground name, canyon of occurrence, and whether the deposit was documented by Case (1989) or our own data collection.

\section{Valley Cross-Profiles}

Cross-valley profiles (44 total) at variable positions within study area canyons were generated using $1 / 3$ arc second $(\sim 10 \mathrm{~m})$ resolution digital elevation models (DEMs) acquired from the USGS National Map Seamless Server. These DEMs were then mosaiced using ArcMap 9.3 from ESRI (Environmental Research Systems Institute). Transect lines for cross-valley profiles were created through shapefile manipulation then exported as 
Excel files containing elevation data using 3-D Analyst in ArcMap 9.3. Several other datasets were created and/or used to aid in cross-profile placement and attribute entry including DEM derived surfaces (aspect, hillshade, slope, contour), orthoimagery (NAIP, DOQQs), satellite imagery (IKONOS-2) available in Google Earth ${ }^{\mathrm{TM}}$, as well as a georeferenced geology map (Love et al., 1992). Excel files containing profile elevation data were then entered into Statistix 9.0 and were used to create polynomial regression lines which produced quadratic equations $\left(\mathrm{y}=\mathrm{a}+\mathrm{bx}+\mathrm{cx}^{2}\right)$ containing the coefficients needed for further analyses.

These coefficients were then added to a master dataset that was used to create regressions for selected variables thought to affect valley crossprofile morphology. Other data, besides valley crossprofile coefficients, were also derived from elevation data, including longitudinal slope at cross-profiles, profile areas, Pinedale ice depth (based on trimline and valley floor elevations), form ratios (Augustinus, 1992; Graf, 1970), shear stress at valley centers, and profile distances from the Teton fault. RMS data were also appended to the new dataset and used in the subsequent analyses involving variations in valley cross-profiles.

Several outputs of analyses mentioned earlier were combined in a master dataset which was then used to describe longitudinal variations in valley cross-profile morphology. This dataset, stratified by profiles, included variables such as profile equation coefficients, profile areas, form ratios, glacier heights, profile slopes, shear stress, rock types, and RMS variables (Table 2).

Form ratios were produced using the equation:

$$
\mathrm{Fr}=\mathrm{W} / \mathrm{D}
$$

where $\mathrm{W}$ is valley width, and $\mathrm{D}$ is valley depth (Graf, 1970).

Shear stress was calculated using the equation:

$$
\mathrm{T}=\rho \mathrm{gh} \sin \alpha
$$

where $\rho$ is ice density (a constant of $900 \mathrm{~kg} / \mathrm{m}^{3}$ ), g is the acceleration due to gravity $\left(9.81 \mathrm{~m} / \mathrm{s}^{2}\right), \mathrm{h}$ is the thickness of the glacier, and $\alpha$ is the slope of the valley (Sugden \& John, 1976). Values derived from this equation are expressed in terms of bars (pressure).

Profile areas were produced using the equation:

$$
\mathrm{A}=2 / 3 \mathrm{WD}
$$

where $\mathrm{W}$ is valley width, and $\mathrm{D}$ is valley depth.

Once compiled, the master dataset for valley cross-profiles was entered into Statistix 9.0 so that summary statistics, correlation matrixes, and multivariate regressions could be performed.

\section{$\uparrow \quad$ RESULTS}

\section{Slope failures}

Shapefiles were created for slope failures, and an example for Cascade Canyon is shown in Figure 4.

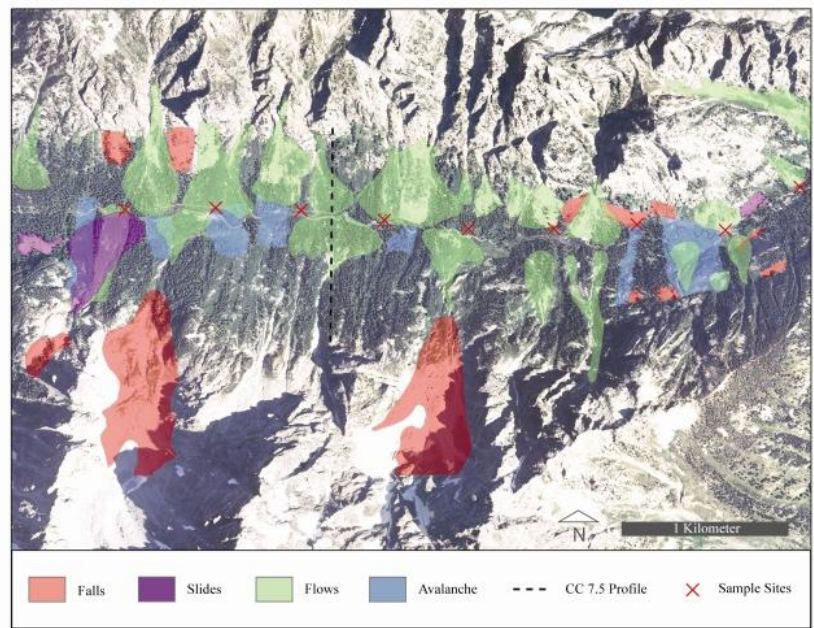

Figure 4. Example of a map of slope failures showing all four types, sample sites, and a single profile line in Cascade Canyon. Maps have been created as shapefiles for all five canyons, provided to the GTNP Resource Management Office.

Inspection of histograms, and Chi-Square analyses for falls reveals that falls occur at the greatest frequency where:

1) Aspect is north-facing with azimuths between 300 degrees and 60 degrees;

2) Distance to the Teton Fault is between 1300 and 3700 meters;

3) Schmidt Rock hammer values are between 50-60, indicating "strong" rock; and

4) Slope gradient lies in the range of 56-62 degrees.

Chi-square analyses revealed that any combination of two or more variables above produces a significant explanation (at $\mathrm{p}<0.0001$ ) for the distribution of falls. 
Inspection of histograms, and Chi-Square analyses for slides reveals that slides occur at the greatest frequency where:

1) Distance to the Teton Fault is between 1300 and 4100 meters and

2) Slope gradient is greater than 49 degrees.

Chi-square analyses revealed that the combination of distance to the Teton Fault and slope gradient produces a significant explanation (at $\mathrm{p}<$ 0.0001) for the distribution of slides.

Inspection of histograms and Chi-Square analyses for flows reveals that flows occur at the greatest frequency where:

1) Aspect is south-facing with azimuths between 140 degrees and 220 degrees;

2) Distance to the Teton Fault is less than 3400 meters;

3) RMS is greater than 60 and

4) Slope gradient lies in the range of 28-54 degrees.

Chi-square analyses revealed that any combination of two or more variables above produces a significant explanation (at $\mathrm{p}<0.0001$ ) for the distribution of flows.

Inspection of histograms, and Chi-Square analyses for snow avalanches reveals that snow avalanches occur at the greatest frequency where:

1) Aspect is north-facing with azimuths between 320 degrees and 40 degrees

2) Distance to the Teton Fault is between 2300 and 4800 meters and

3) Slope gradient lies in the range of 32 and 48 degrees.

Chi-square analyses revealed that any combination of two or more variables above produces a significant explanation (at $\mathrm{p}<0.0001$ ) for the distribution of snow avalanches.

The "disturbance regime" found in the Teton Range is likely the result of major climate changes that have occurred since the end of the Pleistocene. These changes, namely warming, led to the relatively recent deglaciation of the range. This removal of ice from Teton canyons, in turn, led to the debuttressing of glacially over-steepened valley walls that has apparently caused them to be unstable, likely through the redistribution of shear stresses as glacial buttressing has been removed. In general, a propensity of mass movement coincides with Pinedale trimlines in many canyons. This appears to be the result of a combination of processes such as glacial debuttressing coupled with slope aspect.

Fault-shattering and variable weathering seems to also have played a role in the frequency of mass movements in Teton canyons by weakening valley walls through continual seismic events that fracture rocks, further enabling the weathering processes to exacerbate those newly created fractures, as well as pre-existing jointing and fractures. These processes can be seen in tandem (variably) with each other throughout all sampled canyons.

Variation in slope-aspect also appears to play a large role in the type and frequency of mass movement in Teton canyons. Because many canyons more/less have east/west strikes, their valley walls are exposed to varying amounts of solar insulation, namely through northerly and southerly aspects. This is most apparent in canyons such as Cascade, Death, and Granite, where there is increased debris flow frequency on the south-facing slopes. This increase in debris flow frequency is likely due to southerly facing slopes receiving increased amounts of solar insulation, which has the effect of increasing the frequency of freeze/thaw cycles experienced on a daily basis, especially in warmer seasons. In contrast, northerly facing aspects have an increased frequency of rock falls and snow avalanches, which are likely the result of more intense frost wedging than would occur on warmer (southerly) aspects.

For the length of trails we surveyed in the field, slope failures covered the following percentages of the trail:

1) Granite Canyon $24 \%$

2) Death Canyon $29 \%$

3) Garnet Canyon $52 \%$

4) Cascade Canyon $31 \%$

5) Paintbrush Canyon $18 \%$

An example of the shapefile showing trails directly intersected by slope failure polygons is presented below as Figure 5.

For the camping zones that we surveyed, the following have been impacted by past slope failures:

1) Death Canyon Campground

2) Meadows Campground, Garnet Canyon

3) Platforms Campground, Garnet Canyon

4) Garnet Caves Campground, Garnet Canyon

5) Granite/Mt. Hunt Campground, Granite 
Canyon

6) Granite-Lower, Granite Canyon

7) Granite Middle/S. Fork, Granite Canyon.

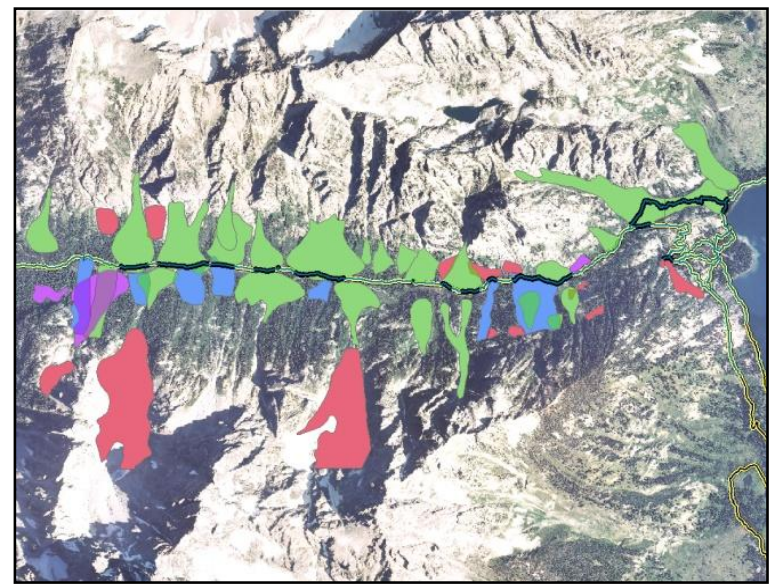

Figure 5. ArcMap 9.3 view of Cascade Canyon, GTNP. The black lines represent lengths of trails intersected by slope failure polygons. Green polygons represent debris and rock flows, red polygons represent rock and block falls, blue polygons represent snow avalanches, and purple polygons represent rock and block slides. Yellow lines represent trail segments not directly intersected by slope failures. Similar shapefiles were created for all five canyons.

An example of the shapefile showing camping zones directly intersected by slope failure polygons is presented below as Figure 6 .

\section{Valley Cross-Profiles}

An example of the valley cross-profiles is presented in Figure 7. The quadratic equation was fit through the points that had been derived from the DEM data.

Table 2 contains descriptive statistics of these variables. From Table 2, it can be seen that all sampled rocks exhibited moderate to strong RMS ratings (53 to 78) according to the classification used by Moon (1984). Rock mass strength (RMS) seems to be a least partially responsible for the quasiuniform cross-valley profiles of study site canyons. Because the range of RMS values for all sample sites fell within the "moderately strong" classification by Moon (1984), the parabolic shapes of cross-valley profiles are maintained as weathering and erosion compete to remove them, despite the somewhat varied lithology within individual canyons.

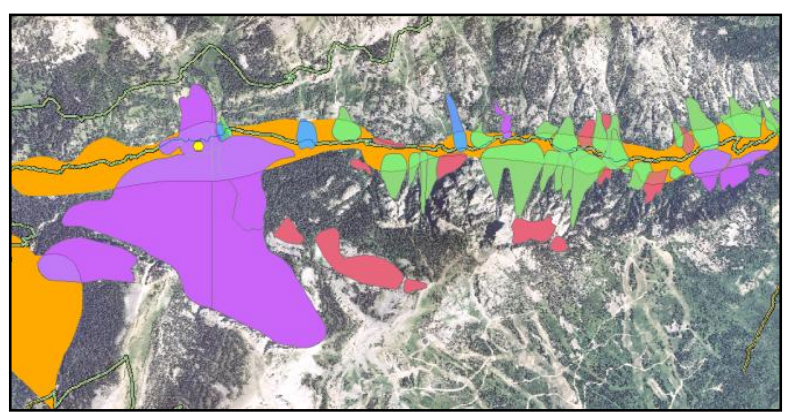

Figure 6. ArcMap 9.3 view of camping zones intersected by slope failure polygons in Granite Canyon, GTNP. Orange polygons represent GTNP Camping Zones, green polygons represent debris and rock flows, red polygons represent rock and block falls, blue polygons represent snow avalanches, and purple polygons represent rock and block slides. Yellow lines represent park trails. Similar shapefiles were created for all five canyons.

\section{Cascade Canyon Profile 7.5}

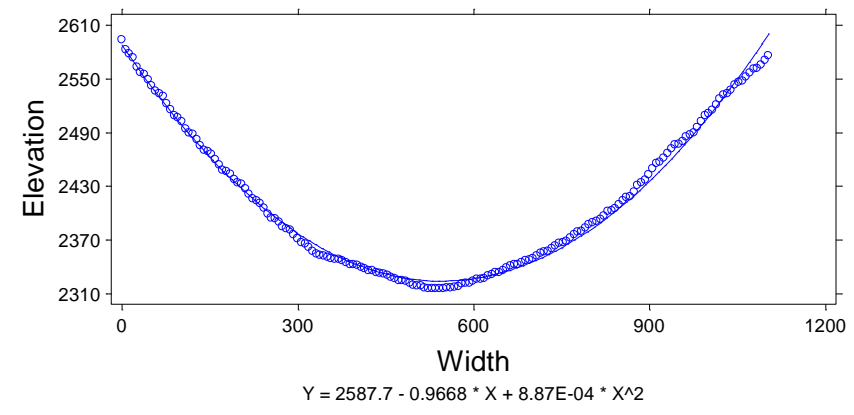

Figure 7. Profile elevation data (circles), the regression line (line), and the equation of the regression line for Cascade Canyon, near site 7. Profiles have been created at 44 locations in the five canyons.

Table 2. Summary statistics of valley cross-profile analyses.

\begin{tabular}{|llcccc|}
\hline Table & Mean & Minimum & Maximum & Standard Dev. & Number \\
Profile Area $\left(\mathrm{km}^{2}\right)$ & 0.159 & 0.016 & 0.586 & 0.114 & 44 \\
C Coefficient & 0.0018 & 0.0005 & 0.006 & 0.0012 & 44 \\
Distance to Fault $(\mathrm{m})$ & 3035.2 & 1000 & 6000 & 1313.2 & 44 \\
Form Ratio & 0.34 & 0.23 & 0.57 & 0.08 & 44 \\
Shear Stress (bars) & 1.6 & 0.07 & 6.9 & 1.6 & 44 \\
Weathering & 8.07 & 7 & 9 & 1 & 41 \\
Joint Spacing & 18.2 & 11 & 28 & 3.8 & 41 \\
Joint Orientation & 12.1 & 5 & 18 & 4 & 41 \\
Joint Width & 4.3 & 2 & 6 & 1.3 & 41 \\
Joint Continuity & 4.5 & 1 & 6 & 1.2 & 41 \\
Groundwater & 4.8 & 3 & 6 & 0.8 & 41 \\
Hammer Value & 49.1 & 32 & 61 & 8.7 & 41 \\
Total RMS & 67.3 & 53 & 78 & 6.7 & 41 \\
\hline
\end{tabular}

Shear stress in the study canyons averaged 1.6 bars, which is comparable to values from the late Pleistocene Yellowstone outlet glacier's 0.8 to 1.2 bars as reported by Pierce (2003). Given that there are several outliers over 6 bars, this average is slightly skewed as shown from Figure 8. 


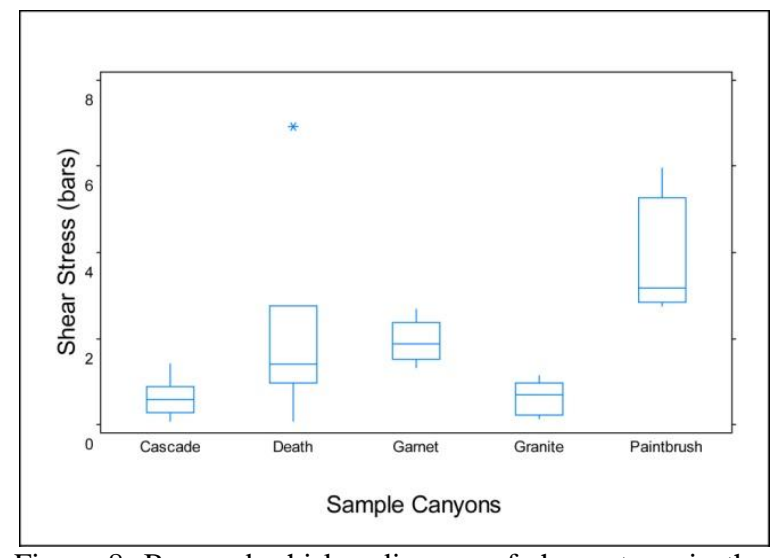

Figure 8. Box and whisker diagram of shear stress in the five study canyons.

These values are not outside the range of past measurements in the region. According to Peirce (2003), Locke (written comm., 2002) calculated shear stress to be as high as 8 bars in the Wind River Range icecap. A potential reason for such high shear stress was reported by Locke (2002) to be funneling of ice into steep and narrow canyons, which can partly explain the high values (6.9 bars) for two profiles in this study (D3 \& D4), which are steep $(0.27 \& 0.31)$ as well as narrowing in the down-valley direction. Other canyons, such as Paintbrush, also have steep gradients (0.24 to 0.32$)$, which increased the inflation of the shear stress average for this study (Figure 9).

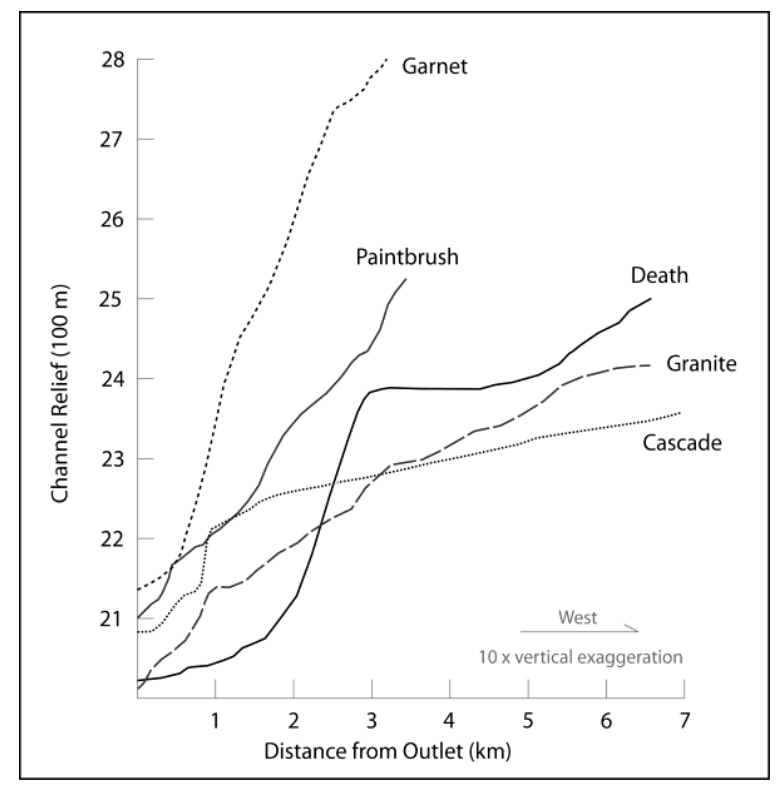

Figure 9. Longitudinal profiles of study site canyons.

In an effort to understand which variables were correlated most to the $\mathrm{C}$ coefficients of valley cross-profiles, a correlation (Pearson) matrix was created. This matrix provided both $\mathrm{r}^{2}$ and $\mathrm{p}$ (correlation and probability) values for all dependent and independent variables from the master dataset. Based on the results of the correlation matrix, variables which had the highest $\mathrm{r}^{2}$ and $\mathrm{p}$ values (concerning the $\mathrm{C}$ coefficient) were used in a stepwise linear regression analysis in Statistix 9.0. This regression included $\mathrm{C}$ coefficients, rock type, hammer values, and joint widths, with a confidence interval of 0.05 (95\%). Results from the regression indicated that rock type and hammer values were strongly correlated to $\mathrm{C}$ coefficients (adjusted $\mathrm{r}^{2}=$ 0.8011 ), having $\mathrm{p}$ values of 0.000 and 0.0024 , respectively. Joint width was excluded from the calculation by Statistix 9.0.

In general, results from multiple valley cross-profile data analyses revealed that (1) all sampled profiles could be curve-fitted to parabolas with high $\mathrm{r}^{2}$ and $\mathrm{p}$ (correlation and probability) values, indicating that the morphologies of the study area canyons are indeed parabolas, and (2) that the $\mathrm{C}$ coefficient of these parabolic forms are strongly correlated to rock type, and Schmidt hammer values, in that as rock type changes from granite to gneiss, and as hammer values increase, the $\mathrm{C}$ coefficient increases (steeper and narrower). A possible explanation of this result is that as rock type changes from coarse grained granite to fine grained gneiss, rock strength increases because of the more homogeneous distribution of minerals in gneiss, allowing for more slope stability at higher slope angles. Schmidt hammer values are also indicative of the compressive strength of rocks, so it is understandable that rocks with higher compressive strengths would be more apt to hold at high slopes following glacial debuttressing.

Detecting variation in cross-valley profiles was complicated, mostly due to the fact that tributary valleys from opposing sides of trunk-streams were rarely symmetrical, that is, a valley on one side of the canyon is not guaranteed to have a counterpart directly across from it, which was also a result found by Seppala (1978). This caused cross-profiles to often have one half that was directly sampling a trunk-stream trimline position, while the other half would be forced to sample a tributary valley, which could be a large, former glacial channel. There were, however, sample sites that afforded cross-valley profiles that sampled both trimline positions. These parabolas, in general, appear to be symmetrical near the tops of trimlines but display less symmetry as one moves toward the valley floor. This asymmetry has caused all study canyon streams to be (variably) incongruent with the former glacial troughs they 
occupy, which is basically the result of mass movement deposits.

\section{MANAGEMENT IMPLICATIONS}

\section{Slope failures}

Approximately 2.7 million people visited Grand Teton National Park in 2010 (US National Park Service, 2010), and thousands of these visitors use the numerous hiking trails that ascend into the glacially carved, parabola-shaped canyons of the park. It is in these canyons that slope failures occur in to an impressive extent, and these failures will undoubtedly have an impact on both hikers and human-built structures such as hiking trails and camping zones. We urge the GTNP Resource Management staff to explore the detailed map overlays showing slope failures, trails, and camping zones and consider replacing those in danger with new sites away from potential slope failures.

\section{Valley cross-profiles}

Glacial valley cross-profiles have been shown to be the shape of parabolas by others and again here in our study. Nevertheless, information to visitors (interpretive signs, guidebooks) provided by the National Park Service and others persist in describing them as "U-shaped". This is an unfortunate choice of terms for deglaciated valleys because it does not describe the true morphology of the form, and because it does not imply genesis either (morphogenetic). A potential replacement, following the needed suppression of the term "U-shaped", could be Parabola-shaped or Parabolic valleys. These are subtle differences in terminology, however, there is truly a distinction to be made. Parabolas, quite simply, are functions in which $\mathrm{y}=\mathrm{x}^{2}$, where the tails of the line become asymptotic as $\mathrm{x}$ approaches infinity. Conversely, the shape of a " $U$ " is a semicircle with parallel tails, or "ascenders" (Figure 10).

In light of the numerous amounts of past literature describing glacial valleys as parabolic, as well results from this study, we suggest that the term $U$-shaped be suppressed, while concurrently promoting the more appropriate term parabolic valley in future park descriptions of glacial valleys.

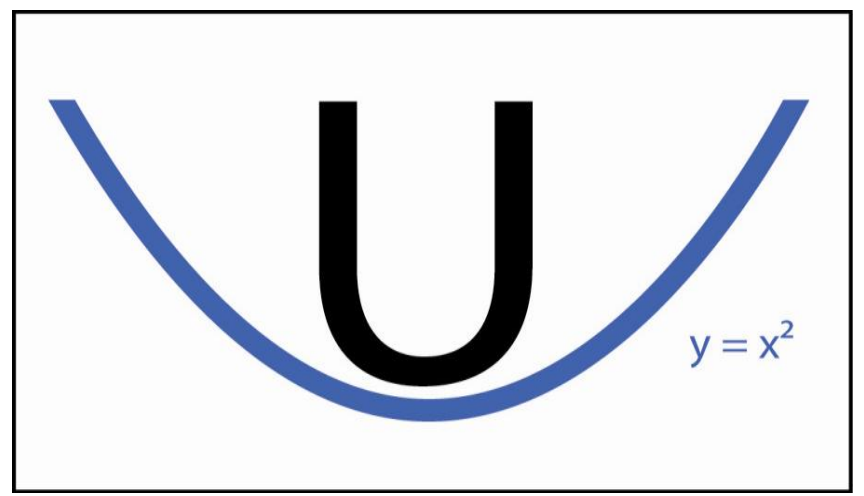

Figure 10. U-shaped vs. parabolic valley cross-profiles.

\section{$\uparrow \quad$ Literature Cited}

Alexander D. 1993. Natural Disasters. Chapman and Hall Publishers, London (UK), 255 pp.

Augustinus PC. 1992. The influence of rock mass strength on glacial valley cross-profile morphology: a case study from the southern Alps, New Zealand. Earth Surface Processes and Landforms 17:39-51.

Augustinus PC. 1995. Glacial valley cross-profile development: the influence of in-situ rock stress and rock mass strength, with examples from the Southern Alps, New Zealand. Geomorphology 14:87-97.

Benda L, Veldhuisen C, Black J. 2003. Debris flows as agents of morphological heterogeneity at low-order confluences, Olympic Mountains, Washington. Geological Society of America Bulletin 115(9):1110-21.

Brook MS, Kirkbride MP, Brock BW. 2004. Rock strength and development of glacial valley morphology in the Scottish Highlands and Northwest Iceland. Geografiska Annaler 86 A (3):225-234.

Brozović N, Burbank DW, Meigs AJ. 1997. Climate limits on landscape development in the northwestern Himalyas. Science 276:571574 .

Burchstead D, Daniels MD, Thorson RM, Vokoun JC. 2010. The river discontinuum: Beavers (Castor canadensis) and baseline conditions for restoration of forested headwaters. BioScience 60(11):908-921. 
Case JC. 1989. Wyoming landslide classification scheme. Geologic Hazards Section, Wyoming State Geological Survey. (www.wrds.uwyo.edu) Last accessed July, 2010 .

Christopherson RW. 2009. Geosystems: An Introduction to Physical Geography. Prentice Hall, Upper Saddle Creek (NJ).

Dackombe RV, Gardiner V. 1983. Geomorphological Field Manual. London (UK), George Allen Unwin.

Davis WM. 1916. The Mission Range, Montana. The Geographical Review 2:267-288.

Degenhardt JD, Giardino JR, Marston RA, Pitty AF.2007. Interpretation of a blockstream in Tom Mays Canyon, Franklin Mountains, Texas. Zeitschrift für Geomorphologie 51(3):377-396.

Foster D, Brocklehurst SH, Gawthorpe RL. 2010. Glacial-topographic interactions in the Teton Range, Wyoming. Journal of Geophysical Research 115:1-20.

Good JD, Pierce KL. 2002. Interpreting the Landscape: Recent and Ongoing Geology of Grand Teton \& Yellowstone National Parks. Grand Teton Natural History Association, Moose (WY).

Graf W. 1970. The geomorphology of the glacial valley cross section. Arctic and Alpine Research 2, 4:303-312.

Harbor JM. 1995. Development of glacial-valley cross sections under conditions of spatially variable resistance to erosion. Geomorphology 14:19-107.

Harbor JM. 1992. Numerical modeling of the development of U-shaped valleys by glacial erosion. Geological Society of America Bulletin 104:1364-1375.

Harbor JM, Hallet B, Raymond CF. 1988. A numerical model of landform development by glacial erosion. Nature 333:347-349.

Harp EL, Wilson RC, Wieczorek, GF. 1981. Landslides from the February 4, 1976, Guatemala earthquake, U.S. Geological Survey Professional Paper 1204-A.
Hewitt K. 2006. Disturbance Regime Landscapes: Mountain drainage systems interrupted by large rockslides. Progress in Physical Geography 30(3): 365-393.

Hirano M, Aniya M. 1988. A rational explanation of cross-profile morphology for glacial valleys and glacial valley development. Earth Surface Processes and Landforms 13:707716.

Hirano M, Aniya M. 1989. Rational explanation of cross-profile morphology for glacial valleys and glacial valley development: a further note. Earth Surface Processes and Landforms 14:173-174.

Hirano M, Aniya M. 1990. A reply to 'a discussion of Hirano and Aniya's (1988, 1989) explanation of glacial valley cross-profile development' by Jonathan M. Harbor. Earth Surface Processes and Landforms 15:379381.

Keefer DK. 2002. Investigating landslides caused by earthquakes: a historical review. Surveys in Geophysics 23:473-510.

Lageson DR, Spearing DR. 1991. Roadside Geology of Wyoming. Missoula (MT): Mountain Press Publishing Co.

Love JD, Reed JC, Christiansen AC. 1992. Geology Map of GTNP, Teton County, Wyoming. Denver (CO): USGS Map Distribution.

Love D, Reed JC, Pierce KL. 2007. Creation of the Teton Landscape: A Geological Chronicle of Jackson Hole and the Teton Range. $2^{\text {nd }}$ ed., Salt Lake City (UT): Paragon Press.

Mahaney WC. 1990. Neoglacial chronology and floristics in the Middle Teton area, central Teton Range, Western Wyoming, Journal of Quaternary Science, 1:53-66.

Marston RA. 2010. Geomorphology and vegetation on hillslopes: interactions, dependencies, and feedback loops. Geomorphology 116: 206-217.

Marston RA, Miller MM, Devkota L. 1998. Geoecology and mass movement in the Manaslu-Ganesh and Langtang-Jugal himals, Nepal. Geomorphology 26:139-150. 
Moon BP. 1984. Refinement of a technique for determining rock mass strength for geomorphological purposes. Earth Surface Processes and Landforms 9:189-193.

Moon BP, Selby MJ. 1983. Rock mass strength and scarp forms in southern Africa. Geografiska Annaler. 65A (1-2):135-145.

Owen G, Matthews JA, Albert PG. 2007. Rates of Holocene chemical weathering, 'Little Ice Age' glacial erosion and implications for Schmidt-hammer dating at a glacier-foreland boundary, Fåbergstølsbreen, Southern Norway. The Holocene 17(6): 829834.

Patten RS, Knight DH. 1994. Snow avalanches and vegetation pattern in Cascade Canyon, Grand Teton National Park, Wyoming, U.S.A. Arctic and Alpine Research 26 (1):35-41.

Pierce KL, Good JD. 1992. Field Guide to the Quaternary geology of Jackson Hole, Wyoming. U.S. Geological Survey Open File Report 92-504.

Pierce KL. 2003. Pleistocene glaciations of the Rocky Mountains. Development in Quaternary Science 1: 63-76.

Plummer C, Carlson DH, Hammersley L. 2010. Physical Geology. $13^{\text {th }}$ ed. New York (NY): McGraw Hill.

Roberts SV, Burbank DW. 1993. Uplift and thermal history of the Teton Range (northwestern Wyoming) defined by fission-track dating. Journal of Earth and Planetary Science Letters 118:295-309.

Selby MJ. 1980. A rock mass strength classification for geomorphic purposes: with tests from Antarctica and New Zealand. Zeitschrift für Geomorphologie 24:31-51.

Selby MJ. 1982. Rock mass strength and the form of some inselbergs in the central Namib Desert. Earth Surface Processes and Landforms 7:489-497.
Seppala M. 1978. Influence of rock jointing on the asymmetric form of the Ptarmigan Glacier Valley, southeastern Alaska. Bulletin of the Geological Society of Finland 47:33-44.

Shroder JF Jr., Weihs BJ. 2010. Geomorphology of the Lake Shewa landslide dam, Badakhshan, Afghanistan, using remote sensing data. Geografiska Annaler, 92A (4):469-483.

Sidle RC, Ochiai H. 2006. Landslides: Processes, Prediction, and Land Use. American Geophysical Union, Water Resources Monograph 18, Washington, D.C., 312 pp.

Sugden DE, John BS. 1976. Glaciers and Landscape. Edward Arnold, London (UK).

Svensson H. 1959. Is the cross-section of a glacial valley a parabola? Journal of Glaciology 3:362-363.

US National Park Service. 2010. National Park Service visitor summary report total recreation. (www.nature.nps.gov/stats/view Report.cfm?selectedReport=SystemYTDByPark. cfm), Last accessed March 11, 2011.

Vankat JL. 1979. The Natural Vegetation of North America. Krieger Publishing, Malbar (FL).

Viles H, Goudie A, Grab S, Lalley J. 2011. The use of the Schmidt hammer and Equotip for rock hardness assessment in geomorphology and heritage science: a comparative analysis. Earth Surface Processes and Landforms 36:320-333.

Wheeler DA. 1984. Using parabolas to describe the cross-sections of glacial valleys. Earth Surface Processes and Landforms 9: 391394.

Wyoming State Geological Survey and the Water Resources Data System, 2001: Preliminary landslide map, Wyoming State Geological Survey, Laramie (WY). 